\title{
Biannual multispecific spawning in Karimunjawa Archipelago, Indonesia
}
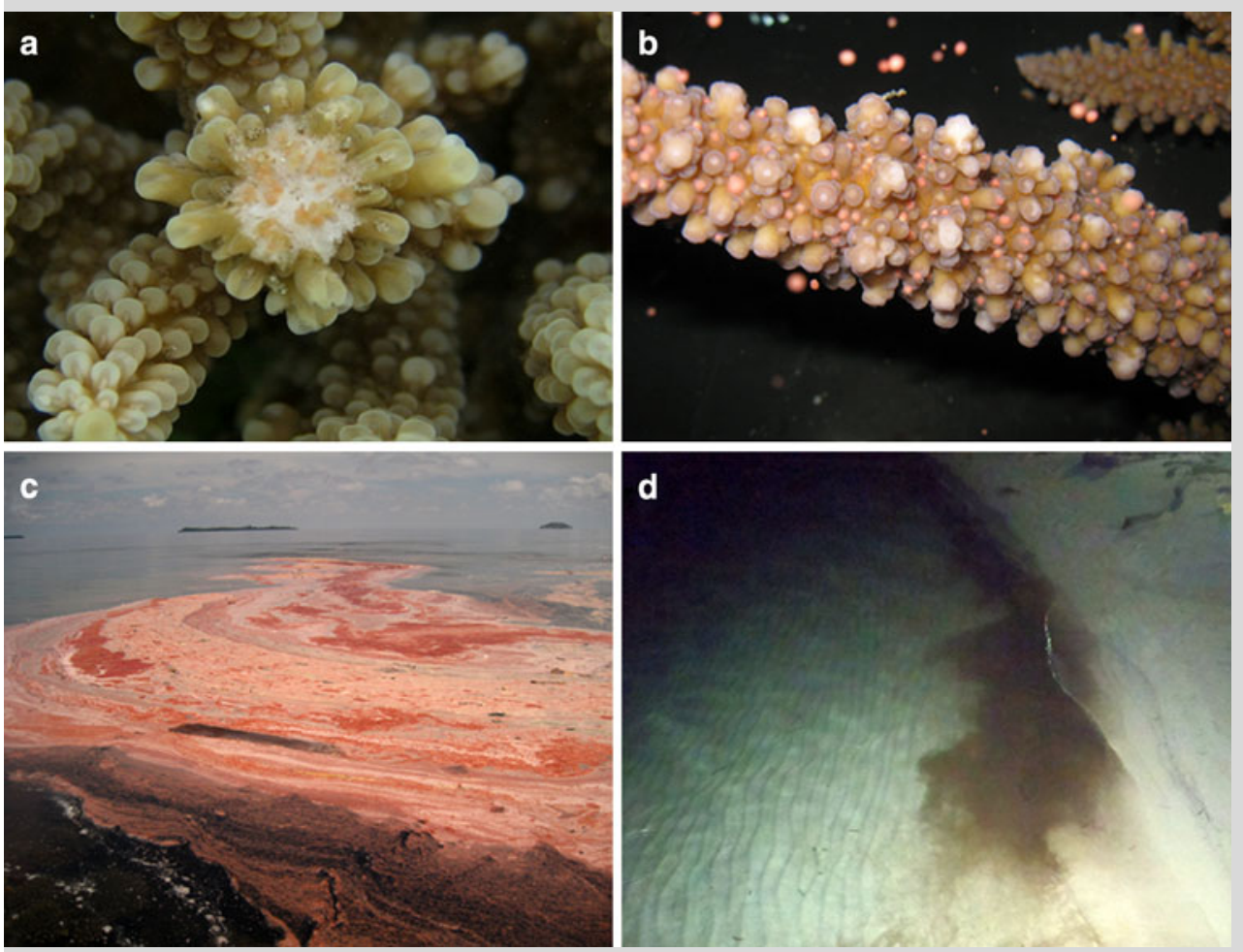

Multispecies synchronous spawning has now been described from 23 regions globally (Baird et al. 2009). The first observation of multispecific synchronous spawning in Indonesia was in the Karimunjawa Archipelago in October 1995 (Edinger et al. in Tomascik et al. 1997). In 2009, the reproductive condition of coral colonies was examined at three sites around Sambangan Island $\left(05^{\circ} 50^{\prime} 39.2^{\prime \prime} \mathrm{S}, 110^{\circ} 35^{\prime} 12.4^{\prime \prime} \mathrm{E}\right)$ along a line transect $(100 \mathrm{~m})$. In March, $40 \%(\mathrm{n}=132)$ of the colonies on these transects contained mature oocytes (Fig. 1a). A total of 53 (of 132) tagged colonies from 8 of 13 species released their gametes between 1940 and 2215 hours on the night of 20 March 2009 (8 days after the full moon; Fig. 1b). Spawning also occurred on 3 April 2009 when 24 of 64 colonies from 6 of 13 species spawned their gametes at the same time of night as the previous spawning.

In 2009 and 2011, multispecific spawning events were recorded in March, April (Fig. 1c), and October; in 2011, spawning occurred in March and September (Fig. 1d). September/October events were dominated by faviids and agaricids, tenuis; b in March A. gomezii released gametes without setting; slicks were seen around Sambangan Island on c 17 March 2011 and $\begin{aligned} & \text { while March/April by acroporids. } \\ & \text { This is the first indication that there } \\ & \text { are two peak periods of spawning in } \\ & \text { the Java Sea, a phenomenon that }\end{aligned}$
appears to be common in Southeast Asia (Guest et al. 2005; Baird et al. 2009) and North Western Australia (Gilmour et al. 2009). The two distinct spawning seasons tenuis; b in March A. gomezii released gametes without setting; slicks were seen around Sambangan Island on c 17 March 2011 and $\begin{array}{r}\text { while March/April by acroporids. } \\ \text { This is the first indication that there } \\ \text { are two peak periods of spawning in } \\ \text { the Java Sea, a phenomenon that }\end{array}$
appears to be common in Southeast Asia (Guest et al. 2005; Baird et al. 2009) and North Western Australia (Gilmour et al. 2009). The two distinct spawning seasons tenuis; b in March A. gomezii released gametes without setting; slicks were seen around Sambangan Island on c 17 March 2011 and $\begin{aligned} & \text { while March/April by acroporids. } \\ & \text { This is the first indication that there } \\ & \text { are two peak periods of spawning in } \\ & \text { the Java Sea, a phenomenon that }\end{aligned}$
appears to be common in Southeast Asia (Guest et al. 2005; Baird et al. 2009) and North Western Australia (Gilmour et al. 2009). The two distinct spawning seasons tenuis; b in March A. gomezii released gametes without setting; slicks were seen around Sambangan Island on c 17 March 2011 and $\begin{aligned} & \text { while March/April by acroporids. } \\ & \text { This is the first indication that there } \\ & \text { are two peak periods of spawning in } \\ & \text { the Java Sea, a phenomenon that }\end{aligned}$
appears to be common in Southeast Asia (Guest et al. 2005; Baird et al. 2009) and North Western Australia (Gilmour et al. 2009). The two distinct spawning seasons appear to be associated with changes in the monsoon that likely are driven by two annual peaks in insolation and or temperature (van Woesik et al. 2006).

Acknowledgments Many thanks to AH Baird for his suggestion on sample collection. DPW received Dikti's Competention Grants.

References

Baird AH, Guest JR, Willis BL (2009) Systematic and biogeographical patterns in the reproductive biology of scleractinian corals. Annu Rev Ecol Syst 40:551-571

Gilmour JP, Smith LD, Brinkman RM (2009) Biannual spawning, rapid larval development and evidence of self-seeding for scleractinian corals at an isolated system of reefs. Mar Biol 156:1297-1309

Guest JR, Baird AH, Goh BPL, Chou LM (2005) Reproductive seasonality in an equatorial assemblage of scleractinian corals. Coral Reefs 24:112-116

Tomascik T, Mah AJ, Nontji A, Moosa MK (1997) The ecology of the Indonesian Seas. Part One. Periplus, Hong Kong

Van Woesik R, Lacharmoise F, Köksal S (2006) Annual cycles of solar insolation predict spawning times of Caribbean corals. Ecol Lett 9:390-398

D. Permata $(\bowtie) \cdot$ E. Indrayanti · D. Haryanti $\cdot$ L. Fika $\cdot$ H. Arfiyan $\cdot$ A. Achmad

Marine Science Department, Diponegoro University, Kampus Tembalang, Semarang, Indonesia

e-mail: diah_permata@mail.com

D. Haryanti

Biology, Chemistry and Marine Science Department, University of the Ryukyus, Senbaru-1, Nishihara, Okinawa, Japan

Received: 20 October 2011/Accepted: 20 April 2012/Published online: 9 May 2012

Coral Reefs (2012) 31:907

(C) Springer-Verlag 2012 